\section{Эффективность методов оценки состояния лесных сообществ на примере ельников Костромской области}

\author{
Н. В. Рыжова ${ }^{1}$ \\ В. В. Шутов \\ Костромской государственный технологический \\ университет
}

\begin{abstract}
АННОТАЦИЯ
Анализируются методы оценки состояния лесных сообществ при организации лесного мониторинга в ельниках Костромской области. Отмечается их пригодность для научных исследований и мониторинга.
\end{abstract}

Ключевые слова: лесное сообщество, популяция, мониторинг, оптимум, пессимум, биоиндикачия.

\section{SUMMARY}

The analysis of the evaluation methods of the forest communities condition under forest monitoring arrangement in the spruce forests of Kostroma region is presented. Their applicability for scientific research and monitoring is marked.

Keywords: forest community, population, monitoring, optimum, pessimum, bioindication.

\section{ПОСТАНОВКА ПРОБЛЕМЫ}

В связи с разработкой методов лесного мониторинга возникла необходимость оценки состояния лесных растительных сообществ в различной экологической обстановке и на разных этапах антропогенной сукцессии. В своей работе мы попытались дать оценку их эффективности и пригодности для ведения лесного мониторинга.

\section{ОБЪЕКТЫ И УСЛОВИЯ ИССЛЕДОВАНИЯ}

Исследования проведены в 2000-2002 гг. в ельниках шести лесхозов Костромской области. Еловые насаждения характеризовались разным возрастом древостоя (от 40 до 400 лет), наличием в его составе не менее 5 единиц ели и в основном кисличными и черничными типами леса. Всего было испытано три метода оценки состояния ельников: популяционный, биоиндикации и лесозащиты. Кроме того, на каждом исследуемом объекте проведены геоботаническое описание растительности и таксация древостоя общепринятыми методами, а также выявлена освещенность под древесным пологом на высоте 1.3 м люксметром.

\footnotetext{
${ }^{1}$ Авторы - соответственно старший преподаватель и профессор кафедры лесоинженерного дела (ㄱ Н. В. Рыжова, В. В. Шутов, 2003
}

\section{РЕЗУЛЬТАТЫ ИССЛЕДОВАНИЯ}

Популяционный метод. Оценку состояния лесного сообщества можно провести путем определения оптимального, пессимального и критического состояния его доминирующих видовых ценопопуляций. В еловых сообществах это будут, прежде всего, популяции ели, березы, осины, черники, брусники, кислицы и др. Пессимальное состояние ценопопуляции растений характеризуется обычно наименьшими показателями большинства ее параметров. Более сложным является содержание понятий оптимального и критического состояния ценопопуляций [1].

Понятие оптимумов у растений в настоящее время сильно запутано по смысловому содержанию, и в литературе они называются по-разному, образуя следующие пары: потенциальный экологический оптимум - реальный оптимум; физиологический - экологический; аутэкологический и синэкологический; экологический - эколого-фитоценотический; экологический - фитоценотический [2].

Фитоценотический и экологический оптимумы обычно не совпадают [3]. Причины этого могут быть различными, например, частичная компенсация экологических факторов и их взаимосвязь друг с другом, фитоценотическая обстановка местообитания вида, конкуренция видов и трансформация растениями факторов среды [2, 4].

Для оценки состояния организма используют, прежде всего, размерные показатели, определяющие мощность растения, например, его вегетативную и репродуктивную биомассу. В ельниках Костромской области часто доминантами травяно-кустарничкового яруса являются кислица, черника, реже брусника и еще реже линнея. По отношению к кустарничковым растениям связь вегетативной и репродуктивной биомасс, по нашим данным [5], может быть до определенного предела положительной, а затем отрицательной, когда вегетативная масса имеет максимальные значения, но плодоношение слабое или вовсе отсутствует. Поэтому важны оба параметра, которые мы склонны рассматривать и в качестве оптимальных. Для оценки состояния ценопопуляций растений, на наш взгляд, целесообразно использовать комплекс признаков. В качестве признаков организма - морфологические параметры (высота и диаметр стволов у деревьев, длина вегетативных побегов и плотность кустов кустарничков, годичный и текущий прирост), а для оценки репродуктивной функции - плотность генеративных особей, число на них цветков, плодов и шишек. Все эти параметры рекомендуется определять для той возрастной группы растений, которая преобладает в ценопопуляции.

Среди популяционных параметров учитывают плотность растений, долю подроста и генеративных растений. Диапазон каждого признака разбивается на 5 классов по равномерной шкале; затем каждому классу присваивается балл (наименьший балл соответствует наименьшим показателям). Положение каждой 
исследованной ценопопуляции ельников оценивается в баллах соответственно величине каждого признака.

Кроме оптимального, важно определить и критическое состояние ценопопуляции. Оно характеризуется рядом популяционных признаков: наличием сухостоя и валежа, сильно неравномерной плотностью, пространственной расчлененностью отдельных особей и их групп, небольшой высотой и малыми приростами, почти полным отсутствием в ценопопуляции подроста.

Критическое состояние необратимо в тех условиях, при которых оно возникло, поэтому выход из критического состояния возможен лишь в результате изменения этих условий. У растений, размножающихся преимущественно вегетативным способом, ценопопуляция в критическом состоянии может существовать довольно продолжительное время.

Используя шкалу жизненности кустарничков [5], мы провели оценку состояния ценопопуляций линнеи, брусники и черники в ельниках Судиславского и Солигаличского районов (26 объектов). Жизненность этих кустарничков менялась от 1 до 5. Так, у линнеи она не превышала 3 , у брусники - 4 и только у черники достигала 5. Основной причиной низких показателей жизненности были низкая освещенность (особенно для брусники), конкуренция со стороны других видов травяно-кустарничкового яруса (особенно для линнеи) и сильные антропогенные нагрузки (для всех видов). Состояние у 16 исследованных ценопопуляций кустарничков определено как оптимальное, у 7 как пессимальное и у 2 - как критическое. Последние находились в условиях очень низкой освещенности (менее 5\% от освещенности открытого места).

Ясно, что по результатам оценки состояния популяций доминирующих видов травяно-кустарничкового яруса трудно оценить состояние всего фитоценоза. Такую оценку следует делать в комплексе, и в первую очередь для ели - основного эдификатора еловых сообществ. Экспериментально было доказано, что ель как мощный эдификатор контролирует и регулирует конкуренцию между видами кустарничков, трав и мхов в подземных частях сообществ и таким образом стабилизирует флористический состав и структурную организацию нижних ярусов экосистем еловых лесов [6]. В то же время низкая жизненность ценопопуляций, доминирующих в травянокустарничковом ярусе, может быть показателем очень напряженного этапа динамики всего фитоценоза, что при оценке состояния всей экосистемы необходимо учитывать. Следовательно, популяционный метод вполне может использоваться для оценки состояния лесных сообществ. Однако он очень трудоемок и требует для каждого вида специальных шкал, которые имеются у небольшого числа видов. Поэтому этот метод более пригоден для научных целей или при изучении отдельных видов растений и их жизненных форм.
Метод биоиндикации основан на учете морфологических изменений растений. К нему относится фиксация изменения окраски листьев или хвои - хлорозы, пожелтение, покраснение, побурение, появление некрозов (точечных и пятнистых, межжилковых, краевых, верхушечных и др.), опадение (дефолиация) листвы и др.

Согласно методике европейского мониторинга лесов [7], дефолиация и дехромация крон деревьев оцениваются в процентах с точностью $5-10 \%$ от количества хвои или листвы, которое дерево могло бы иметь в отсутствие повреждающих факторов.

Наиболее распространенным видом древесных растений-биоиндикаторов, используемых при мониторинге лесов, является ель. При оценке дефолиации кроны ели рекомендуется оценивать $1 / 3-1 / 2$ часть, так как в нижней части кроны оценка дефолиации осложнена потерей хвои из-за недостатка освещения и наличием большого количества вторичных побегов, которые трудно отличить от первичных. Очень важно также определить возраст хвои. В средней полосе России возраст хвои ели обычно составляет 4 - 7 лет [7].

Используя методику определения степени дефолиации и дехромации крон ели, мы провели специальные исследования в ельниках пригородных лесов г. Костромы, в Судиславском и Кологривском районах (34 объекта). Дехромация крон ели не превышала 1 класса повреждения деревьев. В основном это было пожелтение хвои вблизи промышленных предприятий и под воздействием весенних заморозков. Отмечены также все типы дефолиации ели, но массового характера она не имела, кроме очагов воздействия корневой губки. Основные причины дефолиации - выбросы промышленных предприятий, подтопление лесных земель, рубки с сохранением подроста, постепенные и выборочные рубки, охлестывание, действия короедов и других вредителей. В целом метод биоиндикации достаточно прост в применении, но более надежен только при выявлении воздействия экстремальных экологических факторов, поэтому в подавляющем большинстве случаев еловые насаждения области оказались в отличном состоянии.

Метод лесозащиты. Более универсальной и гибкой является шкала категорий состояния деревьев, поврежденных насекомыми и лесными пожарами, разработанная специалистами лесозащиты [8]. Здоровые деревья оцениваются баллом 1 , ослабленные - 2 , сильно ослабленные -3 , отмирающие -4 , свежий сухостой -5 , старый сухостой -6 . Исходя из этого, здоровые древостои имеют индекс $1.0-1.5$, ослабленные - 1.6-2.5, сильно ослабленные - 2.6-3.5, усыхающие - 3.6-4.5, сухостой - свыше 4.5. Таким образом, оценка состояния лесного сообщества полностью проводится только по древостою.

С помощью этой шкалы нами проведена оценка состояния древостоев в пригородных лесах г. Костромы. Были взяты три объекта: 1 - лесной массив за микрорайоном Малышково, 2 - Посадский лес и 3 - 
дендропарк Пригородного лесничества. Объекты подобраны в порядке возрастания рекреационной нагрузки от умеренной до сильной. Результаты оценки жизненного состояния деревьев представлены в таблице.

Судя по среднему баллу повреждаемости, самое большое число больных и отмерших деревьев в лесном массиве за микрорайоном Малышково, что объясняется средневозрастностью насаждений, которые, как правило, на этом этапе антропогенной сукцессии имеют наибольший процент отмирающих деревьев в связи с дифференциацией древостоя. Здесь явно требуется проведение санитарно-выборочных рубок. Большое число ослабленных (поврежденных) деревьев в дендропарке объясняется сильными рекреационными нагрузками. В целом оценка лесов на всех объектах показала их ослабленное (2.0), сильно ослабленное (2.8) и отмирающее (3.9) состояние, норма здорового насаждения - индекс 1.0-1.5.

Таблица

Жизненное состояние деревьев ели в пригородных лесах г. Костромы

(числитель - число деревьев, знаменатель - сумма баллов жизненности)

\begin{tabular}{|l|c|c|c|}
\hline \multirow{2}{*}{$\begin{array}{l}\text { Классы жизнен- } \\
\text { ности и балл по- } \\
\text { вреждаемости }\end{array}$} & 1 & 2 & 3 \\
\cline { 2 - 4 } Здоровые - 1 & $50 / 50$ & $165 / 165$ & $45 / 45$ \\
\hline Ослабленные - 2 & $20 / 40$ & $25 / 50$ & $105 / 210$ \\
\hline $\begin{array}{l}\text { Сильно ослаб- } \\
\text { ленные - }\end{array}$ & $25 / 75$ & $15 / 45$ & $45 / 135$ \\
\hline Отмирающие - 4 & $40 / 160$ & $15 / 60$ & $5 / 20$ \\
\hline $\begin{array}{l}\text { Свежий сухостой } \\
-5\end{array}$ & $50 / 250$ & $10 / 50$ & $20 / 100$ \\
\hline $\begin{array}{l}\text { Старый сухостой } \\
-6\end{array}$ & $65 / 390$ & $20 / 120$ & $30 / 180$ \\
\hline $\begin{array}{l}\text { Итого } \\
\text { - }\end{array}$ & 5 & $250 / 490$ & $250 / 690$ \\
\hline $\begin{array}{l}\text { Средний балл } \\
\text { повреждаемости } \\
\text { деревьев }\end{array}$ & 3.9 & 2.0 & 2.8 \\
\hline
\end{tabular}

*Наименования объектов по номерам приведены в тексте.

Следовательно, этот метод позволяет отследить воздействие на насаждение не только рекреационных нагрузок, но и естественных процессов самоизреживания древостоя на разных этапах антропогенной сукцессии. Сам метод не трудоемок и вполне применим в любых экологических условиях, что играет большую роль при обработке значительных массивов поврежденных лесов и малой численности исследовательской группы.

В заключение следует отметить, что состояние лесных сообществ отражается на их видовом разнообразии, или биоразнообразии. По данным наших исследований, в общем флористическом списке ельников Костромской области насчитывается 196 видов сосудистых растений, 81 вид мхов и 29 видов лишайни- ков, что указывает на относительно высокую степень их биологического разнообразия. Проведенные нами ранее исследования [9] показали, что биологическое разнообразие ельников возрастает с усилением антропогенных нагрузок, так как при этом создаются условия, благоприятные для вселения в еловые фитоценозы видов, нехарактерных для них, например, сорных или луговых растений. На основании этого можно сделать вывод, что состояние лесных сообществ определяется не только количеством их элементов, но и характером самих элементов и способов их сочетания. Поэтому ассоциация ельника черничного, состоящая из небольшого числа видов растений (26-30 видов), характеризовалась значительно лучшим состоянием, чем ельника кисличнощитовникового, состоящая из большого количества видов растений (40-60) и испытывающая сильные рекреационные нагрузки. По-видимому, возможна разработка специальной шкалы оценки состояния ельников или степени антропогенной нагрузки на них по особенностям видового состава и уровню биоразнообразия.

Лесные экосистемы хорошего состояния обладают, как правило, высокой устойчивостью. Особенно, если процессы отмирания и возобновления, идя параллельно или чередуясь, взаимно уравновешивают друг друга. Это наглядно можно проиллюстрировать на примере первобытного лесного массива Кологривский лес. В его ельниках деревья 350-400-летнего возраста достигают высоты 40 метров и диаметра 80120 см. Запас древесины на 1 га составляет 480-550 кубометров. Устойчивость и долговечность здесь обусловлены тем, что ельники непрерывно возобновляются, имея в составе деревья всех возрастов - от всходов до старых гигантов. Когда выпадают деревья старых поколений, их место заполняется десятками молодых деревьев. Благодаря такой динамике полог древостоя имеет мозаично-ступенчатое строение, что и определяет устойчивость и бесконечную долговечность лесов. В таком первобытном ельнике процессы разрушения экосистемы (отмирание старых деревьев ели) и процессы созидания (непрерывное возобновление ели) хотя периодически колеблются в ту или иную сторону, но уравновешиваются во времени и экосистема всегда остается устойчивой [10]. Все это доказывает необходимость учета при оценке состояния ельников характера их возобновления.

\section{ВЫВОДЫ}

Для оценки состояния лесных сообществ, особенно в научных целях, можно использовать популяционный метод, основанный на применении комплекса признаков как популяционного, так и организменного уровней. При этом состояние ельников можно определить как оптимальное, пессимальное или критическое на основе ценопопуляции основного эдификатора данного фитоценоза - ели, но с обязательным учетом доминирующих ценопопуляций травянокустарничкового яруса. При осуществлении лесного мониторинга применение этого метода ограничено недостатком популяционных шкал оценки состояния популяций многих видов. 
В условиях сильного антропогенного загрязнения атмосферного воздуха при организации мониторинга предпочтителен метод биоиндикации, который определяет степень дефолиации и дехромации хвои или листвы.

Метод лесозащиты, основанный на использовании шкалы категорий состояния деревьев, позволяет отследить воздействие на насаждение рекреационных нагрузок, поэтому его лучше применять в зеленых зонах городов.

В целом же организация мониторинга в лесах области требует комплексного использования разных методов оценки состояния лесных сообществ в зависимости от экологических условий территорий. Для целей мониторинга довольно информативными могут быть исследования особенностей видового состава ельников, их биоразнообразия и процессов отмирания и возобновления ели.

\section{СПИСОК ЛИТЕРАТУРЫ}

1. Заугольнова Л. Б. Структура популяций семенных растений и проблемы их мониторинга: Автореф. дис. ... докт. биол. наук. СПб. 1994. 70 с.

2. Ипатов В. С., Кирикова Л. А. Фитоценология: Учеб. пособие. СПб.: Изд-во СПбГУ, 1997. 316 с.
3. Шенников А. П. Введение в геоботанику. Л.: Изд-во ЛГУ,1964. 448 с.

4. Работнов Т. А. Вопросы изучения состава популяций для целей фитоценологии // Проблемы ботаники. М.; Л.,1950. Т.1. С. 465-483.

5. Шутов В. В. Структура, динамика и плодоношение популяций кустарничковых растений: Автореф ... д-ра биол. наук. СПб., 2001. 32 с.

6. Факторы регуляции экосистем еловых лесов / Под ред. В. Г. Карпова. Л.: Наука, 1983. 318 с.

7. Устойчивое управление лесным хозяйством: научные основы и концепции: Учеб. пособие / А. С. Алексеев, С. Келломяки, А. В. Любимов и др.; Под общ. ред. А. В. Селиховкина. СПб., 1998. 222 c.

8. Санитарные правила в лесах Российской Федерации. М., 1998. 18 с

9. Шутов В. В., Рыжова Н. В., Рыжов А. Н., Останин А. Н. Влияние рекреационных нагрузок на флористический состав и обилие видов ельника кислично-щитовникового (Костромская область) // Бот. журн. 2001. Т. 86. № 2. С. 63 - 69.

10. Письмеров А. В. Лесной резерват "Кологривский лес" // Природа Костромской области и ее охрана. Ярославль: Верх.-Волж. кн. изд-во, 1987. C. 7-10. 